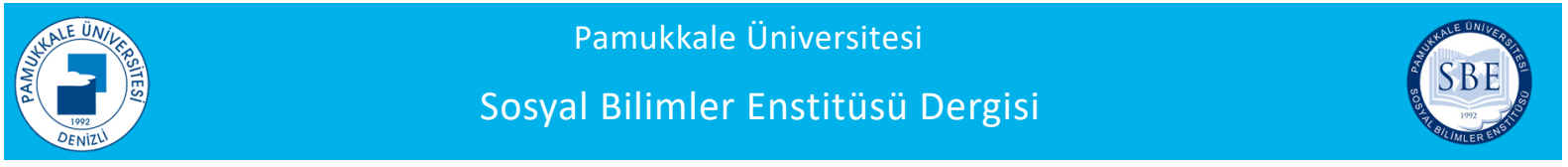

Pamukkale University Journal of Social Sciences Institute

Article Info/Makale Bilgisi

VReceived/Geliş:16.08.2020 VAccepted/Kabul:29.04.2021

DOI:10.30794/pausbed.781192

Araştırma Makalesi/ Research Article

Islam, M. N. (2021). "Turkish Charm and Public Diplomacy: A Literature Review and Critical Assessment on Turkish Soft Power in The Middle Eastern Countries" Pamukkale Üniversitesi Sosyal Bilimler Enstitüsü Dergisi, Sayı 47, Denizli, ss. 175-187.

\title{
TURKISH CHARM AND PUBLIC DIPLOMACY: A LITERATURE REVIEW AND CRITICAL ASSESSMENT ON TURKISH SOFT POWER IN THE MIDDLE EASTERN COUNTRIES
}

\author{
Md. Nazmul ISLAM*
}

\begin{abstract}
The history, political values, economy, foreign policy, culture and geography is a very important tool to exercise the consistent soft power policy and strategy in the world where Turkey's soft power has that kind of capacity that comes from its "history, culture and geography". The new Turkish domestic and foreign policy shows that the policy of the current Turkish government is very effective and strategic to apply their charm in foreign policymaking. The area of Balkans, Caucasus, Middle East, Africa, South/Southeast Asia and South America are not out of Turkish soft power policy involvement, engagement and participation even the new Turkish public diplomacy is covering and expanding its soft power impacts on this society very excellently and efficiently. The last decade's Turkish policy engages with their old allies and continues their relations using countless soft power policies and strategies which shows that Turkey as a new emerging actor from the regional and global context. The main argument of this paper is to show Turkey's soft power policy towards Middle Eastern countries by identifying the Turkish common historical, geographical, religious, cultural, economic and political ties with this region. Accordingly, this paper further analyzes and argues the Turkish Soft Power Policy by taking case assessments and reviews in the literature to explore the economic, political influence like a democratic and economic model to some extent and cultural impacts particularly in lieu of the current government soft power policies, practices and strategies of AKP model, historical ties, Turkey's humanitarian assistance, TIKA's development works, the activities of Yunus Emre Institute, YTB scholarship, Turkish Religious Foundation (Diyanet Vakfi) humanitarian and religious roles and also the Turkish Drama Series impacts on the Middle Eastern societies.
\end{abstract}

Keywords: Turkish Soft Power Policy, Middle Eastern Countries, Turkish Soft Power Institutions, Turkish Foreign Policy and Public Diplomacy.

\section{TÜRK TILSIMI VE KAMU DIPLOMASISI: ORTA DOĞU ÜLKELERINDE TÜRKIYE'NIN YUMUŞAK GÜCÜNE iLIŞKIN BiR LiTERATÜR INCELEMESI VE ELEŞTiREL DEĞERLENDiRME}

öz

Tarih, siyasi değerler, ekonomi, dış politika, kültür ve coğrafya, Türkiye'nin yumuşak gücünün "tarihinden, kültüründen ve coğrafyasından" gelen bu tür bir kapasiteye sahip olduğu dünyada tutarlı yumuşak güç politikası ve stratejisini uygulamak için çok önemli bir araçtır. Türkiye'nin yeni iç ve dış politikası, mevcut Türk hükümet politikasının, dış politika yapımında ülkenin çekiciliğini çok etkili ve stratejik olarak kullanıldığını göstermektedir. Balkanlar, Kafkaslar, Ortadoğu, Afrika, Güney/ Güneydoğu Asya ve Güney Amerika bölgeleri, Türkiye'nin yumuşak gücünün etkileri dışında kalmamaktadır. Türkiye yeni kamu diplomasisinin kapsayıcılığı, angajmanı ve katılımı etkin bir şekilde toplumu kapsamakta ve genişlemektedir. Son on yılın Türk politikası, eski müttefikleriyle ilişki kuruyor ve sayısız yumuşak güç politikası ve stratejisi kullanarak ilişkilerini sürdürüyor, bu da Türkiye'nin bölgesel ve küresel bağlamda yeni ortaya çıkan bir aktör olduğunu gösteriyor. Bu makalenin ana argümanı,

\footnotetext{
*Assistant Professor Dr., Ankara Yildirim Beyazit University, Faculty of Political Science, Department of Political Science and Public Administration, ANKARA.

e-mail: nazmulislamglobal71@gmail.com, (https://orcid.org/0000-0002-8660-0415)
} 
Türkiye'nin Ordatoğu Bölgesiyle olan ortak tarihi, coğrafi, dini, kültürel, ekonomik ve siyasi bağlarını belirleyerek, Türkiye'nin Ortadoğu ülkelerine yönelik yumuşak güç politikasını göstermektir. Buna göre, bu makale, bir ölçüde demokratik ve ekonomik bir model gibi ekonomik, siyasi ve kültürel etkileri özellikle mevcut hükümetin yumuşak güç politikaları çerçevesinde araştırmak üzere literatürdeki vaka değerlendirmelerini ve incelemeleri alarak Türk Yumuşak Güç Politikasını daha ileri düzeyde AKP modelinde tarihi bağlar, Türkiye'nin insani yardımları, TiKA'nın kalkınma çalışmaları, Yunus Emre Enstitüsü faaliyetleri, YTB bursu, Türkiye Diyanet Vakfı (Diyanet Vakfı) insani ve dini rolleri gibi yumuşak güç politikaları, uygulamaları ve stratejileri ve ayrıca Türk Drama Dizisinin Ortadoğu toplumlarına etkisini analiz etmekte ve tartışmaktadır.

Anahtar kelimeler: Türk Yumuşak Güç Politikası, Orta Doğu Ülkeleri, Türk Yumuşak Güç Kurumları, Türk Dış Politikası ve Kamu Diplomasisi.

\section{INTRODUCTION}

Turkish strategic importance seemed (Islam, 2017; Islam, 2019; Nyadera and Islam, 2020; Islam, 2020a; Islam, 2020b; Islam, 2020c) to be exposed to the world after the end of the Cold War particularly the west understands the geostrategic importance of Turkey even Turkey's policy towards the world has risen from grassroots to the upstairs level. Moreover, since the 2002 AK party period; Turkey's domestic and foreign policy have enormous impacts on every corner of the world where especially in terms of the soft power policy, Turkey plays very important contribution whatever it is from cultural impacts, economic participation, political values, humanitarian aid or historical ties and maintaining old allies (Islam, Bingöl \& Nyadera, 2020; Islam, Bingöl \& Nyadera, 2021; Islam, Önder \& Nyadera, 2020; Islam, 2020; Islam, Bingöl, Nyadera \& Dagba, 2021).

In the world, while most of the states such as "China, Germany, France, Russia, Brazil and India spend a lot of time and money to manufacture national narratives in a top-down manner, some others, such as the U.S., do it in a bottom-up manner through the agency of non-governmental organizations and civil society" (Oguzlu, 2017 and Islam \& Cansu, 2018; Islam \& Cansu, 2020). Nevertheless, Turkey is doing their soft power policies and practices both in top-down and bottom-up approaches such as Turkey's government institutions working in a field-level as a tool of top-down approaches "through their governmental institutions, for example, TIKA, AFAD, Yunus Emre Institute (YEE), Diyanet Foundation, Presidency of Religious Affairs, Istanbul Metropolitan Municipality, State Hydraulic Works, State Airport Authority, Ministry of Health, The Presidency of Turks Abroad and Related Communities (YTB), Anadolu Agency, TRT World and Turkish Red Crescent activities, policies, practices and strategies to the world as well Turkey's non-governmental organizational roles through the bottom-up ways like IHH Turkey, Yardimeli, IGMG Hasana Association, Bashir Association, Cansuyu, The Deniz Feneri, and Arakan Platform working activities in different parts of the world” (Ekşi \& Erol, 2018; Ekşi, 2018; Islam and Cansu, 2018).

However, Turkey's foreign policy orientations to the countries of the Middle East have become potentially more significant. "The changing relationship between Turkeys-uniquely positioned in both the West and the East-and its neighbours in the Middle East have great discussion from soft power policy impacts" (Carley, 1994). Increasing acceptance of Turkish external policy among Middle Eastern common people and governments initiates from its economic situations, "Muslim and Islamic identity" (Ekşi, 2016; Islam \& Hossain, 2020), good leadership and political values, pro-Palestine and its probable \& effective role for Iran, Egypt and Qatar (Anas, 2010).

\section{METHODOLOGY AND THEORETICAL APPROACH}

"The methodology is the functional action strategy to carry out the study in the light of the theoretical framework and guiding research question. The study is basically based on the qualitative method from the research analysis of the previous theoretical discussion and empirical description from literature especially from related books and journals on Turkey's soft power policy towards Middle Eastern countries. Secondary data is used for the reanalysis of previously collected and analyzed data. There are clear advantages to working with an existing body of data, such as the reduction of costs, saving time and making difficult populations accessible" (Punch, 1998 and Bingol and Islam, 2016). In order to collect secondary materials, it has been used many books, journals, libraries and relevant websites are related to Turkey's soft power policy. 
Over the past 30 years, scholars, researchers, and practitioners of international|relations have been indicating a great paradigm change in commercial activity (Nyadera and Islam, 2020). In order to understand the theoretical background of Turkey's soft power policy and its impact on the Middle East, some theoretical framework which evaluates Turkey's realpolitik, constructive soft power policy, practice and strategy such as "soft power policy" where the main theorist of soft power policy, Joseph S. Nye, Jr. coined that "soft power" is the "ability of states to get what they want through the power of attraction and persuasion, rather than the power of coercion or payment' where he highly recommend that the attraction and persuasion can be cultural, economic, diplomatic, political values, foreign policies and personal relations (Nye, 2004: 1-4). In the description of Soft Power, Nye included that "the United States should focus on five critical areas: Alliances, partnerships, and institutions, Global development, Public diplomacy, Economic integration Technology and innovation" (Nye 2006). In an earlier article, Nye says that "the ability to affect what other countries want tends to be associated with intangible power resources such as culture, ideology, and institutions" (Nye, 1990). He reasserts that "the Soft Power of a country has three primary sources: its culture (in places where it is attractive to others), its political values (when it lives up to them at home and abroad), and its foreign policies (when they are seen as legitimate and having moral authority)" (Nye, 2004). According to this theoretical understanding, it can be argued that Turkish soft power and public diplomacy institutions already get the trust-able leadership position all over the world, especially by their enormous humanitarian activities, particularly Turkey's assistance which increased Turkey's soft and positive image all over the world. Moreover, their political moves against the USA decision on the 'Jerusalem issue' legitimate their moral authority to the world. Additionally, the Turkish drama series impact the world particularly in the Middle East which shows its credibility and cultural attractions to the other countries.

From the 'constructive theoretical perspective' which can be employed in the process of identity construction to focus on identity, construction is shaped "to transcend what has traditionally been posited as a mutually exclusive dichotomy between ideational and instrumentalist dynamics: the aim is to understand how actor's interest-based strategies are socially formed by longer-term values" (Dal, Dipama, \& Belder, 2014). Accordingly, Alexander Wendt (1994) claims that "the international system is created and recreated in the process of interaction and therefore, it is this inter-subjective rather than material aspect of structures which influence behaviour. Social-constructivist approaches assume that a country's foreign policy agenda is not only shaped by material, but also essentially by an immaterial factor such as ideas, role identities, norms, and values". Turkish engagement with Middle Eastern nations and also their relations with other countries based on humanitarian and Muslim identity based could be a good instance to understand the Wendt (1994) constructive theory. Wendt asserts that "interests presuppose identities because an actor cannot know what it wants until it knows who it is" (Wendt 1999: 231), which fully see the "social relationships" (Ron Jepperson et al 1996: 59).

However, to the constructive scholars, as like Wendt (1999), identity is an important tool for continuing the trustable relations between two states, as he argued that "Actors do not have a 'portfolio' of interests that they carry around independent of social context; instead, they define their interests in the process of defining situations" (Wendt 1999: 398). And in there, "corporate identity refers to the intrinsic, self-organizing qualities that constitute actor individuality" (Wendt 1994: 385). To Wendt (1994), four types of reasons shaped the external relations of any states through the process of identity, such as "(1) physical security, (2) predictability in relationships to the world, (3) recognition as an actor by others, and (4) economic development" (Wendt 1994: 385).

Certain that states interests will be served through the domestic and systematic relations between two countries, as Wendt (1994) argued that "depends on how it defines the self in relation to the other, which is a function of social identities at both domestic and systemic levels of analysis" (Wendt 1994: 385). In his article, Wendt (1994) explained and defined the social identity as "a set of meanings that an actor attributes itself while taking the perception of others, that is, a social object" (Wendt 1994: 385). Similarly, Youngs (2001) discussed the process of identity and its formation in the case of bilateral and external relations, as he claims that the "particular norms coming to be seen as appropriate, that is genuinely embedded in belief systems rather than adhered to for merely instrumental reasons." (Youngs 2001: 6). 
Accordingly, this may sound very obvious that the development assistance and humanitarian aid-based diplomacy of Turkey with the Arab and MENA region somehow resemble the constructive way of partnership. "Turkey's Total Development Assistance (TDA) for 2015 has amounted to a total of 5.105 billion USD. This development assistance, which went to over 150 countries, and all those projects were implemented at the request of the recipient countries. In fact, it's one of the factors that most of the recipient countries are acknowledging the Turkish Assistance Model. It was provided by Turkish NGOs and private establishments, and by over 70 Turkish public bodies under the principles of the authentic Turkish Development Assistance Model" (TIKA Report, 2105). In reality, "Turkey provided the largest share of its bilateral development co-operation to Syria, Somalia, Kyrgyzstan, Albania and Afghanistan. The main sectors for Turkey's bilateral development co-operation were humanitarian aid and refuge support, governance and civil society, education, health and population" (OECD, 2017).

Ibrahim Kalin (2011) argued that

"the key factor that defines a Turkey's soft power capacity is its political system. The most important among those elements which pave the way for a country to achieve a soft power status and make it a centre for attraction is a political system which prioritizes freedoms and liberties, guarantees fundamental rights and freedoms, and which is also just, transparent and democratic. In this regard, one of the main pillars of Turkey's soft power is its democratic experience. Despite the ups and downs in its history, the strengthening of Turkish democracy and its gaining of legitimacy among the public play a significant role in Turkey's position as a regional and global actor. For instance, the "Arab Spring" which began with popular uprisings in Tunisia and Egypt in early 2011 highlighted Turkey's democratic experience in the Middle East. Turkey's democratization efforts and success in economic development have been an inspiration for the newly emerging social and political movements in the Arab world" (Kalin, 2011).

Kalin (2011) also addressed that

"Turkey's soft power is different from that of other countries in its form and content. Turkey's soft power potential, which extends from the Balkans and the Middle East to inner parts of Central Asia, emerges from the cultural and historical experience it has inherited. The values Turkey represents, as well as its history and cultural depth, have mobilized regional dynamics and provided opportunities for the creation of new spheres of influence. In the larger EuroAsian landmass, the common denominator for Turks, Kurds, Bosnians, Albanians, Circassians, Abkhazians, Arabs, Azeris, Kazakhs, Kyrgyzs, Uzbeks, Turkmens and other ethnic groups, as well as Armenian, Greek, Jewish and Assyrian communities is the Ottoman experience they have shared and built together. It is this Ottoman heritage that brings together these diverse groups and enables them to relate to a shared experience in time and place. Today, Turkey represents the pivotal point of this heritage. This is not a new imperial adventure, termed by some as "NeoOttomanism." Rather, this is a process whereby Turkey's new geopolitical imagination and the new possibilities in the global political system allow the people of the region to reconcile with their history and geography. Remembering this experience plays an important role in defining the spheres of soft power in Turkey" (Bilgin, Elis, Beng, Altunışık and Altınay, 2008). ${ }^{1}$

\section{LOGICAL FACTS TO ASSESS THE TURKEY'S SOFT POWER IMPACTS IN MIDDLE EASTERN COUNTRIES}

There are 11 the Middle East and North African (MENA) countries included discussing this region such as Algeria, Bahrain, Djibouti, Egypt, Iran, Iraq, Israel, Jordan, Kuwait, Lebanon, Libya, Malta, Morocco, Oman, Qatar, Saudi Arabia, Syria, Tunisia, United Arab Emirates, West Bank and Gaza, and Yemen where Ethiopia and Sudan are sometimes included.

\footnotetext{
1 "For the concept of soft power in international literature and its meaning for Turkey", see the essays by Bilgin, Elis, Beng, Altunışık and Altınay in the special soft power issue of Insight Turkey, Vol. 10, No. 2 (April-June 2008).
} 
The main facts behind this selection are Turkey's good and specific historical relations, old allies, geographical position, political and strategic reason, economic facts and ideological objects. If we analyze very specifically, for instances;

"Turkey and Egypt share deep-rooted relations, based on close historical, cultural and social ties, common ideological goals which starting from the earliest stages of the Tahrir Revolution back in January 2011, Turkey supported the legitimate demands of the Egyptian people and steps towards democratization in Egypt. Nevertheless, the coup that took place on 3 July 2013 and led to the ousting of the first democratically elected President, Mohammed Morsi, and the consequent derailment of the natural progress of the democratization process of the country, has adversely affected the relationship between Turkey and Egypt. Based on a principled stand on the issue, Turkey advocates the view that Egypt's long term political and economic stability and development can only be achieved by respecting people's democratic will without exclusion" (Ministry of Foreign Affairs, Turkey, 2020).

On the other hand, Iran is a neighbouring country of Turkey with which Turkey shares a $560 \mathrm{~km}$ long border, unchanged for almost 400 years. Also, both Turkey and Iran put importance on each other by their diplomatic ties such as

“...the Turkish Embassy in Tehran, there are also Turkish Consulates General in Tabriz, Orumiyeh and Mashhad. Iran is represented in Turkey by its Embassy in Ankara, and its Consulates General in İstanbul, Trabzon and Erzurum. Turkish-Iranian bilateral relations are evolving based on the principles of non-interference in domestic affairs, mutual respect and good neighborliness. Efforts are made to further enhance the political dialogue both on bilateral and regional issues, through reciprocal visits and mechanisms such as High-Level Cooperation Council and joint commissions in different sectors" (Ministry of Foreign Affairs, Turkey, 2020).

More specifically, at the time of the Iranian nuclear deal; Turkey has huge impacts to come out of this agreement in reality between P5+1 countries. Finally, the importance of Turkey-Qatar relations depends on-

"possesses deep-rooted friendship and fraternity ties and enjoys excellent relations. The bilateral relations between the two countries are rapidly improving in all fields. Intensive bilateral visits at all levels and in all fields add a major impetus to bilateral relations between Turkey and Qatar. Both countries also closely coordinate and cooperate on regional issues. Cooperation with the Gulf Cooperation Council (GCC) constitutes another pillar of Turkey's bilateral relations with Qatar. In this regard, the High-Level Strategic Dialogue mechanism existing between Turkey and the GCC also provides a useful platform for Turkey's cooperation with Qatar on bilateral and regional issues. As of 2016, the bilateral trade volume between Turkey and Qatar (excluding petroleum and its derivatives) stands at 710 Million USD. The value of projects Turkish construction companies have so far undertaken in Qatar exceeds 15 Billion USD. The Qatari capital has a steadily increasing interest in Turkey, which already possesses important investments in the country" (Ministry of Foreign Affairs, Turkey, 2020).

Most importantly, recent Turkey's move to support Qatar against the Saudi led coalition suppression which makes the very good both soft and smart power impacts between Turkey-Qatar relations.

\section{TURKEY'S SOFT POWER VISION IN THE MIDDLE EAST}

"Although we are talking different languages in this vast geography, we should not forget that we have one history, one culture and similar values. We have given a shape to the history together. Be sure that we will give a shape to the future altogether. We are the members of a civilization that gives high importance to neighbourhood" (Prime Minister Recep Tayyip Erdogan, 25 November 2010). 
To understand the Turkish current foreign policy, it is very important to know the current AKP manifesto "2023 vision" which exemplifies the 'active, responsible and successful foreign policy' whose first step as Davutoglu says is "to integrate Turkey's foreign-policy discourse into its national discourse". Western scholars like Graham E. Fuller (2008) \& Heinz Kramer (2010) projected three scenarios of Turkish foreign policy including Washington-oriented, Brussels oriented and Independent foreign policy. Some scholars argue that the last one 'independent foreign policy, sometimes represent the Turkish foreign policy which may enter Muslim countries and Islamic oriented foreign policy.

Many suggest that "the foreign policy shifts are directed to restoration. Ottomanism and emergence of neo-Ottomanism. Ahmet Davutoglu, academic turned foreign minister of the Turkish republic in Justice and Development Party (Adalet ve Kalkinma Partisi-AKP) regime is somehow considered as the architect of new Turkish foreign policy till 2015. In that time, Davutoglu prescribes successful foreign policy operation under strategic depth guided by five key principals" (Davutoglu 2008: 79-84).

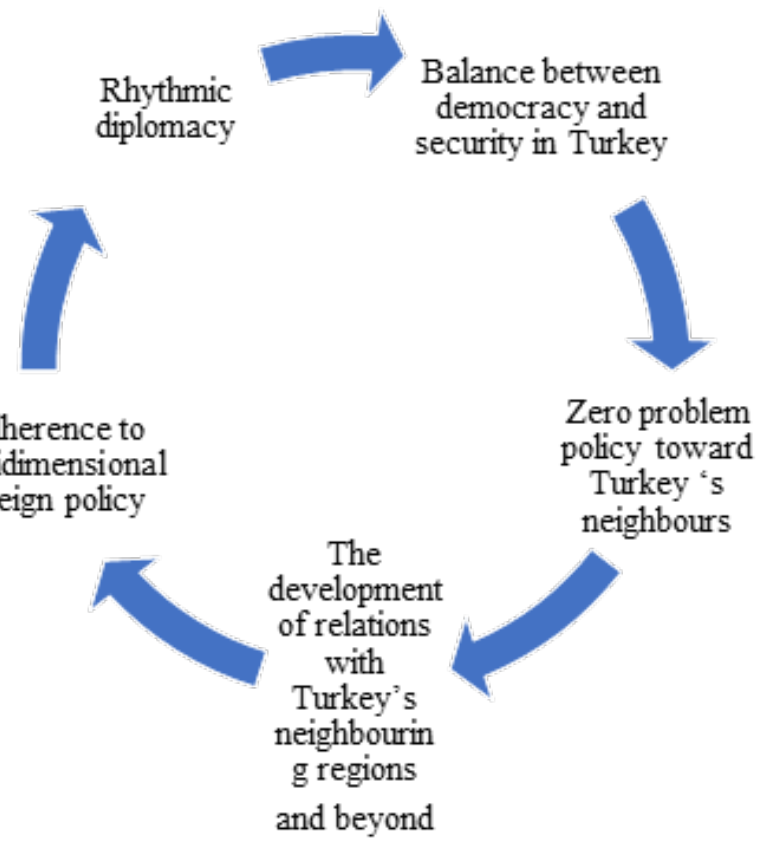

Figure 1: Five Key Principles of Turkish Foreign Policy under Strategic Depth by Ahmet Davutoglu (2008)

“Turkey's key concerns in the region are unresolved Iranian nuclear issue, instable and insecure Iraq, increased Palestine-Israel tensions along with problems in the Caucasus, Balkan and Cyprus. Turkey aims to be an energy hub by making itself which requires Turkey to become a buying and selling center as well as a transit country, it makes Turkey's foreign policy important to the Middle East from the energy sector. Additionally, The Ottoman-Islamic bond has been seen as an ideological base for future cultural and political partnerships by Islamic political parties of the region" (Anas, 2010). Most importantly, the business investors from the Middle East; Turkey tries to attract them to create a new business secured hub and environment even Turkey's active engagement and leadership role in different regional and international organizations- for example, Organization of Islamic Cooperation (OIC) and League of Arab States (LAS) and African Union; Turkey holds their strategic partnership status even the recent effective leadership role against US decision on "Jerusalem issue"; it strongly shows Turkey's leadership position to the world as well as in the region.

Western scholars mainly argue that Turkey is the role model for MENA regions and their government's democratization process (Altunisik 2005; Bal 2000; Fuller: 2004, 2008, Mohapatra: 2001). Turkish economic progress and consistent performance show that Turkey is worthy of development and leading economy country for its region and international attention that doesn't have oil or energy but can be a good economic model for its neighbouring countries and its regions. 


\section{TURKEY'S COMMON SOFT POWER INSTITUTIONS INFLUENCES AND IMPACTS IN THE MIDDLE EAST}

Table 1: Turkey's Soft Power Institutions Influence and Impacts in the Middle East

\begin{tabular}{|c|}
\hline Soft Power Institutions Influence and Impact \\
Arab Perception to Turkey \\
\hline Instrumental Use of Soft Power \\
\hline Turkey's Economic Model or AKP as a Model \\
\hline Turkish Drama in the Arab World \\
\hline Turkish President Recep Tayyip Erdogan Speech as a Tool of Soft Power \\
\hline Recent Humanitarian Assistance \& TIKA's Role Increased Turkish Soft \& Positive Image in the Middle East \\
\hline Turkish Public Diplomatic Institutions Impacts on the Middle East \\
\hline
\end{tabular}

\subsection{Instrumental Use of Turkish Soft Power in the Middle East}

Turkey's foreign policy has been able to accommodate middle eastern nations, those with rightist and religious thoughts among regional public and government reformers as a constructive economic model. The end of the Cold War, the two Iraq wars, the conflict in Afghanistan, the crisis with Iran, and the recent global financial crisis moulded and re-moulded Turkish foreign policy" (CARNEGIE Middle East Center, 2011). Sabiha Senyücel Gündoğar (2011) asserted that "the Arab perception of Turkey is overwhelmingly positive, while the inverse is not true".

The head of Center for Strategic Studies' Mohamed Noureddine (2011) argues that Turkey was able to achieve its positive image in Middle Eastern nations due to its charismatic President, Recep Tayyip Erdogan leadership such as “Erdogan's 2009 public argument with Israeli President Peres at Davos" (One Minute), Flotilla Mavi Marmara Incident in 2010, Turkey's support of demonstrators against Egyptian President Hosni Mubarak in Tahrir Square since 2011 to until now, even more interestingly the Influence of Turkish cuisine especially the Ottoman cuisines are very popular in the Middle East. Reformers in the Middle East endeavour to emulate the Turkish model, which Mohammad Noureddine (2011) explained is based on three pillars: "democratic transformation, economic development, and a reformed foreign policy that exports solutions".

\section{2. Turkish Drama in the Middle Eastern Countries}

Recent statistics show that "Turkey is the second-highest exporter of TV series abroad globally after the United States. Turkish series have been exported to over 100 countries, contributing to a boom in the country's domestic television industry" (Gulf News, 2012). "Nearly 150 Turkish television series have been sold to over 100 countries in the Middle East, Eastern Europe, South America and South Asia. It is common to see groups of Arab or Iranian tourists in Istanbul visiting the alluring sites they have seen on screen" (New York Times, 2017). Turkish series including Diriliş Ertuğrul, Kuruluş Osman, Payitaht Abdülhamid, The Magnificient Century (Muhteşem Yüzyıl), Soaps \& Noor are influencing the Middle East.

Turkish TV dramas have great impact heroically on the Arab community, for example, Ibrahim El-Amiri (2016) argues in his thesis paper on the impact of Turkish TV dramas on the Middle East, believes the Middle East has found its own hero in the state-hired hand in a Turkish TV drama. He also shows that "the reason why Turkish dramas are so popular is that they relate to Eastern culture, particularly in religious matters. The concept of religion is seriously seen in these shows, which causes them to be watched more in the Arab world" (Al-Amiri, 2016) even also he said, "The Valley of the Wolves (Kurtlar Vadisi)" was an especially big hit. "The hero of this drama, Polat Alemdar, is one of the most important heroes of the Arab world. He is seen as a hero who always fights against cruelty and the Zionists. The film 'The Valley of the Wolves: Iraq' had a great impact on Arab countries and is watched all the time" (Al-Emiri, 2016).

Some empirical data shows the value of Turkish drama year by year as an example; A deep Khair, General Manager and owner of Sama Art Productions, a Syrian TV production company which dubs Turkish dramas into 
colloquial Syrian Arabic said "I bought a one-hour (one hour of copyright) Turkish drama for $\$ 600[D h 2,203]$ or $\$ 700$. Today, there are [parties] who are willing to pay $\$ 40,000$ for one-hour [dramas]," More interestingly,

"the last two episodes of Nour "Gümüş" (Silver), shown on August 30, 2008, attracted 85 million viewers in the Middle East and North Africa [Mena] region, out of which 50 million were females. MBC, which started broadcasting Turkish dramas in 2008, has telecast nearly 20 series. The others are shown on Arabic satellite channels such as Abu Dhabi TV and Dubai TV"' (Zayed, 2013).

According to the Guardian news report, "just a decade ago the international sale of Turkish television dramas amounted to less than 1 million U.S. dollars, and in just a few years it managed to reach 50 million dollars in 2010, due primarily to the huge success of those shows in the Middle East" (The Guardian, 10th October 2012).

\section{3. Turkish President Recep Tayyip Erdogan Speech as a Tool of Soft Power}

Many non-western scholars argue that Turkish President Erdogan's speech is a very instrumental tool for influencing the soft power policy especially in the Muslim and Arab world such as Erdogan speech in 13th OIC Summit expressed that "As I have always expressed, my religion is neither Sunni nor Shi' ite, I am a Muslim. Just like my 1.7 billion siblings, I am purely and simply a Muslim. All the other differences come after this belief and title of mine". Moreover, the nationalist concept of 'One nation, one flag, one homeland, one state'; many Islamist scholars argued that it can be the good "Ummah" concept for Muslim nations even the sign what Turkish President shows in his all political campaign "Rabia Sign" is also very good influential policy to attract the Muslim people in the Arab region.

Additionally, Erdogan's ideological correlational basis speech which indicates the Turkish history particularly the lost history of Muslim Ummah makes sense to the rightist and religious motivated person and when it comes to the Arab region then it has huge impacts from politically, culturally and religiously, for example, to indicate the Dirilis Ertugrul drama series; Erdogan said "Until the lions start writing their own stories, their hunters will always be the heroes," which gives a great message to his fellow political party, civilian and in the Arab region.

\section{4. Recent Humanitarian Assistance and TIKA's Role Increased Turkish Soft \& Positive Image in the Middle East}

According to the Global Humanitarian Assistance Report, "Turkey became the 2nd biggest donor country of the world following the USA in 2015 with an official humanitarian aid of 3,2 billion US Dollars" (TIKA Report, 2015). Turkey also became the "most generous country", "taking into consideration the ratio of Turkish official humanitarian assistance to its national income in the same year. On the other hand, according to unofficial data, Turkey's humanitarian assistance reached 5.7 billion US Dollars in 2016" (OECD Report, 2017).

As it is already rationalized \& actualized that Turkish soft power institutions already get the trust-able leadership position all over the world by their enormous humanitarian activities particularly Turkey's assistance which increased Turkey's soft and positive image to all over the world especially in the Middle East, for example, the Turkish assistance for Syrian Refugees since 2013, earthquake between Iraq-Iran on 14th November 2017, Arakan Crisis and Turkish Role from August 25, 2017, Somalia Droughts and Recent Bombing in Somalia where Turkey assisted 40 People for their health support in Ankara (Islam and Cansu, 2018). Additionally, "the SouthEast Asia earthquake in December 2004, Pakistan earthquake in 2005, Humanitarian crisis in Lebanon in 2006, Gaza Crisis at the end of 2008, Haiti and Chile earthquakes, Flood disaster in Pakistan in 2010, Japan earthquake in 2011, Typhoon in Philippines, Floods in the Balkans, Attacks to Gaza in 2014, Earthquake in Nepal, Conflict in Iraq in 2015, Humanitarian crisis in Yemen, Libya in 2015-2016, Flood in Macedonia in 2016" (Ministry of Foreign Affairs, Turkey, 2020) have huge positive, influential impacts in the MENA region.

\section{5. Turkish Public Diplomatic Institutions Impacts on the Middle East}

Yunus Emre Institute (YEE) Summer School Program for the Middle East, for example, "Yunus Emre Institute's Cultural Centres Coordinator, Associate Professor Mustafa Balcl, emphasized the importance of the language programs for their role in Turkey's increased 'soft-power throughout the world, particularly in the Middle East 
and the Balkans" (Çelık, 2015) which shows the Turkish great strategy and effective plan for MENA region by acquiring the soft power institution like YEE.

Additionally, YTB has a very good number of scholarship for MENA regions especially for Syria, Iraq and Palestinian students which also creates the very good image of Turkey in this region and prepare the future foreign ambassador in those particular countries who will be contributing good role for continuing bilateral relations between the Turkey and host countries.

Most importantly, TIKA's project on medicine, agriculture, hospitals, a central library such as in Iraq \& Palestine creates a long-term impact on this region. Turkey also intensified its mediation efforts that included mediation between Syria and Iraq, Syria and Israel and Hamas and Israel, Jerusalem issue, India and Pakistan over Kashmir issue (Islam, 2016 and Islam, 2019), Rohingya issue between Bangladesh and Myanmar (Islam and Rahman, 2018), Academic Conferences, Seminars related to the Middle East.

Turkey's cooperative attitudes in the time of the Iranian Nuclear Deal with P5+1 gives a good space for Turkey to deal with so many issues of MENA. Although this is true that the increasing popularity of Turkish soft products is being perceived as Turkish inroad into Muslim world once again and the Turkish drama serials like "Noor" or "Dirilis Ertugrul" were called "Return of Ottoman". An Iranian newspaper wrote that Saudis are supporting Turkey in the Arab World only to counter Shia Iran.

"To counter the Shia culture and reduce its moral influence on the Shias of the Arab World, the Saudis shrewdly provided Turkish Prime Minister Recep Tayyip Erdogan access to their publicity organs so that Turkey could begin playing a more active role in the political, cultural, and economic life of the Middle East" (Tehran Times 28 August 2008).

Anyway, the common approach both Iran and Turkey in the time of Arab Spring make them friendly relations but this can be argued that what is happening in the Middle East now, one of the most responsible countries is Iran especially in terms of Syria and Yemen conflict. Turkish refused to be part of the P5+1 country jointly sanctions against Iran which were approved by UNSC. Some primary data shows that the modern and secular people of Iran love to stay in Turkey because of its free society, freedom and democracy even the good number of Iranian students studying in Turkey and want to study in Turkey as their first choice.

Recent Saudi led countries hostile attitudes and Sanction on Qatar and Turkey's humanitarian aid such as Food Aid, Media Campaign by TRT World have a very effective and positive impact on Qatari People and the Qatari Government even to settle and manage this crisis, Turkish President Erdogan's shuttle diplomacy in Saudi Arabia, Kuwait, and Qatar give trust-able leadership position to Qatar even more than USA policy towards this crisis.

\section{CHALLENGES OF TURKEY'S SOFT POWER POLICY IN THE MIDDLE EAST}

This can be assumed that Turkey's soft power institutions have a great role in the MENA region but there are so many potential conflicts arising in the Middle East specifically the proxy war between Iran and Saudi-USAIsrael led countries makes Turkey very challenging position to take a decision even the proclamation by Saudi led allies about Islam based ideological political parties like Muslim Brotherhood is a terrorist party; creates a very undecided situation for continuing theirs with this kind of parties.

Additionally, the aggressive role of UAE and Saudi Arabia especially so many irrational decisions taken by Saudi Arabia crown prince Mohammad bin Salman makes instability in the MENA region which also shows that Turkey will take a strategic foreign policy in the region. Moreover, Turkey's weakened relations with the United States and EU and the complicated relations with Russia \& Iran makes them a mysterious space in MENA regional politics.

Overall, it can be said that Turkey's policy towards the Middle East must be shaped through smart power policy-oriented where both hard and soft power will be instrumentalized as what utilized during the Qatar crisis, for example; they have military in Qatar, at the same time they have good soft power impacts on Qatar. 


\section{CONCLUSION}

Turkey possesses important resources and values unique to itself where Turkey's own international relations and priorities based on its short, mid and long-term primary and secondary interests and it will define the soft power policy arena and strategies to its Arab vision. According to Ibrahim Kalin (2010)

"...the concept of soft power depends upon the "carrot and stick" dialectic of American power. However, it is not always possible or even desirable to use the carrot-stick dialectic in the geopolitical environment of a country like Turkey. Rather, a new geopolitical imagination and a notion of common memory, conscience, and cultural depth shape soft-power relations. Turkey's achievement of an effective soft power status depends on its ability to mobilize these dynamics. As a result of the changes it has been going through, Turkey today has a 'new story' and a "new narrative" (Kalin: 2010).

As it is greatly argued in an international political system that "in every context, more cooperation rather than less is the best way to arrive at an unparalleled solution" (Islam, 2020). "The effective communication of soft power policy and strategy indicates that the new "Turkish story" is rising and emerging trust-able leadership position in the world which can be only possible 'through the participation of Turkish soft power actors that function in the public, private and non-governmental sectors' where both soft and smart power tools, policies and strategies can be used in terms to achieve the realpolitik domestic and foreign policy interest of Turkey" (Islam and Cansu, 2018).

Though, this kind of leadership position gives Turkey huge responsibilities and legitimacy for their public diplomacy maintenance, sustainability and long-term basis policy-making and strategy where Turkey will have a national interest both from domestic and foreign policy arena and they can be part of those host countries policymaking and policy implementation process like other unilateral and multilateral countries doing to ensure their national interest and protecting their leadership legitimacy. Now, the world facing a leadership vacuum that "demands the new world order and new leadership from economically, politically and culturally where Turkey can fill up that leadership vacuum and write a new history for tomorrow's world" (Islam and Cansu, 2018 and Islam, 2017).

\section{REFERENCES}

Al-Emiri, I. (2016). Turkish hero 'impacts the Middle East'. Hurriyet Daily News Paper, January 30, 2016. Accessed: 06.012.2017. Retrieved from http://www.hurriyetdailynews.com/turkish-hero-impacts-the-middleeast--94497

Anas, O. (2010). Turkey's Soft Power Challenges in the Arab World. Conference Proceeding at First Arab Turkey Congress of Social Sciences at Ankara on 11 December 2010.

Armstrong, W. (2017). "What a TV Series Tells Us About Erdogan's Turkey". New York Times, November 04, 2017. Accessed: 05.12.2017. Retrieved from https://www.nytimes.com/2017/05/14/opinion/erdogan-tvshow-turkey.html

Bilgin; Elis; Beng; Altunışık; and Altınay (2008). In the special soft power issue of Insight Turkey, Vol. 10, No. 2 (April-June 2008)

Bingöl, Y. \& Islam, M. N. (2016). "The Myth and Reality of Turkish Civil-Military Relations: A Quest from the Case of FETO's July 15th Failed Military Coup Attempt”, Journal of Youth Research, Vol. 4, Number 10, p. 67-86. Retrieved from http://yayinlar.gsb.gov.tr/Public/Files/GAD_10.Sayi.pdf

Carley, P. (1994). Turkey's Role in the Middle East. Paperworks United States Institute of Peace

CARNEGIE Middle East Center. (2011). Turkey's Relations with a Changing Arab World. Accessed: 03.12.2017. Retrieved from http://carnegie-mec.org/2011/05/03/turkey-s-relations-with-changing-arab-worldevent-3150

Çelik, M. (2015). Yunus Emre Institute celebrates "The Voice of 1000 Years: Turkish Language Festival”. August 22, 2015, Daily Sabah. Available at https://www.dailysabah.com/turkey/2015/08/22/yunus-emre-institutecelebrates-the-voice-of-1000-years-turkish-language-festival 
Dal, E. P., Dipama, S. \& Belder, F. (2015). “Assessing Turkey's Development Aid Policy towards Africa: An Constructivist Perspective", 14th METU Conference, 17-19 June, 2015, Ankara. 14th METU Conference, 1719 June 2015, Ankara.

Davutoğlu, A. (2008). Turkey's Foreign Policy Vision: An Assessment of 2007. Insight Turkey, Vol. 10, No.1, pp. $79-84$

Ekşi, M. (2016). AK Parti Döneminde Ortadoğu'da Türk-Amerikan İlişkilerinin Jeokültürel Ekseni: İslami Kimlik. Akademik Bakış, Cilt 9 Sayı 18: 59-77.

Ekşi, M. (2018). Kamu Diplomasisi ve AK Parti Dönemi Türk Dış Politikası. Ankara: Siyasal Kitabevi

Ekşi, M. (2018). The Rise and Fall of Turkish Soft Power and Public Diplomacy. Akademik Bakış, Cilt 11 Sayı 23: 15-45.

Fuller, G. E. (2008). The New Turkish Republic: Turkey as a Pivotal State in the Muslim World, Washington, DC: United States Institute of Peace Press. pp 17. See Zubaida, Sami (1996) "Turkish Islam and National Identity" Middle East Report April-June (10-15) also see Mohapatra, Ak (2008), "Democratization in the Arab World: Relevance of the Turkish Model", International Studies 45: 271.

Fuller, G. E. (2008). The New Turkish Republic: Turkey as a Pivotal State in the Muslim World, Washington, DC: United States Institute of Peace Press., also, Heinz Kramer (2010) “AKP's New Foreign Policy between Vision and Pragmatism, working paper, German Institute of International and security Affairs", June: Berlin.

Gulf News Agency (2012). “Challenge of the Turkish soap operas,” GulfNews, April 1, 2012

Heper, M. and Sule T. (2003). "Islam, Modernity, and Democracy in Contemporary Turkey: The Case of Recep Tayyip Erdogan". The Muslim World, April 2003, Vol 93.

Islam, M. N., Bingöl, Y., and Nyadera, I. N. (2021). Towards Islam through Political Parties, Ideology and Democracy: A Discourse Analysis on AK Party in Turkey, Ennahda Movement in Tunisia and Jamaat-e Islami in Bangladesh, Jadavpur Journal of International Relations, 25 (1).

Islam, M. N. and Hossain, M. (2020). “Islam, Governance and Political Culture in Bangladesh: in Ali Farazmand (Ed.) Global Encyclopedia of Public Administration, Public Policy and Governance, Springer Nature, Switzerland.

Islam, M. N. (2020). Turkey, Asia Anew and South Asia: A Comparative Assessment on Bilateral Relations and Soft Power Policy with Bangladesh, India, and Pakistan. TURAN-SAM Uluslararası Bilimsel Hakemli Dergisi; 47(3), 379-398. DOI: http://dx.doi.org/10.15189/1308-8041

Islam, M. N. (March 2020). Rethinking Turkey-Iraq Relations: The Dilemma of Partial Cooperation by Mehmet Akif Kumral, New York: Palgrave Macmillan. Insight Turkey, 22(1):257-260. ISBN 9781137561237 Available at: https://www.insightturkey.com/book-reviews/rethinking-turkey-iraq-relations-the-dilemma-of-partialcooperation

Islam, M. N. and Cansu, E. E. (2020). “BRI, CPEC, and Pakistan: A Qualitative Content Analysis on China's Grand Strategies", International Journal on World Peace, Vol. Xxxvii No. 3: 43-71

Islam, N. (2020a). Bangladesh: Turkey's key partner in Asia Anew initiative. Daily Sabah, 25 December 2020. Available at https://www.dailysabah.com/opinion/op-ed/bangladesh-turkeys-key-partner-in-asia-anewinitiative

Islam, N. (2020b). Türkiye'nin Yeniden Asya girişimi ve Bangladeş, Anadolu Ajansi, 16 October 2020. Available at: https://www.aa.com.tr/tr/analiz/turkiye-nin-yeniden-asya-girisimi-ve-banglades/2008381

Islam, M. N. (2020c). Bangladeş, Türkiye'nin Asya girişimindeki kilit ortağı olacak, Interview by Ihlas Haber Agency, 03 October 2020. Available at https://www.iha.com.tr/istanbul-haberleri/banglades-turkiyeninasya-girisimindeki-kilit-ortagi-olacak-2712455/

Islam, M. N., Bingöl, Y. and Nyadera, I. N. (2020). "Political and Administrative Culture in Turkey's AK Party, Tunisian An-Nahada, and Bangladesh Jamat-e Islam" in Ali Farazmand (Ed.) Global Encyclopedia of Public Administration, Public Policy and Governance, Springer Nature, Switzerland

Islam, M. N. (2019). Emerging Global Organizations and Groups: A Paradigms Shift for New World Order. ADAM AKADEMi Sosyal Bilimler Dergisi (ADAM Academy Social Sciences Journal), 9(2), 471-490. DOI: 10.31679/ adamakademi.508998 
Islam, M. N. (2019). Güç, strateji ve potansiyeller: Çin ordusunun temel yetenekleri ve faktörleri üzerine bir inceleme (Power, strategy and potentials: a study on the factors and key capabilities of China's military). Cappadocia Journal of Area Studies, 1, 100-110, DOI: http://dx.doi.org/10.38154/cjas.13

Islam, M. N. (2019). Küresel İlişkilerde Doğru Pozisyon Almak: Hindistan Güvenlik Stratejisinin Öncelikleri ve Zorlukları (Assuming Rightful Place in Global Affairs: Priorities and Challenges of India's Security Strategy). M5 Journal, National Security, Defense and Strategy, 44, 335. Available at: https://m5dergi.com/sonsayi/makaleler/kuresel-iliskilerde-dogru-pozisyon-almak-hindistan-guvenlik-stratejisinin-oncelikleri-vezorluklari/

Islam, M. N. and Cansu, E. E. (2018). Humanity First: The Turkish Version of Soft Power. November 23, 2018, Daily Sabah. Available at https://www.dailysabah.com/op-ed/2018/11/23/humanity-first-the-turkish-version-ofsoft-power

Islam, M. N. and Rahman, M. H. (2018). "The Humanitarian Question of Rohingya Muslim Refugee Crisis Beyond the Foreign Policy of Bangladesh and Myanmar: Forced Migration, Identity Linkage and Demographic Assessment of their Historical Exclusion and Statelessness". In Haluk Selvi, ibrahim Şirin, Yusuf Adigüzel, Murat Lehimler, Ali Yeşildal, Raşit Fidan, Hasan Yilmaz, Hayriye Sözer and Muzaffer Sabur (Eds.), Göç Mültecilik ve Insanlik (Migration, Refugee and Humanity), Kocaeli Municipality Press, Kocaeli: Turkey. Takım No: 978-6055116-66-8, ISBN: 978-605-5116-67-5

Islam, M. N. (2016). Devlet Doğasının Değişimi: Güvenliğin Sınırları (Change in State Nature: Boundaries of Security). Istanbul: Turkish Asian Center for Strategic Studies (TASAM). ISBN: 978-605-4881-24-6

Islam, M. N., Önder, M., \& Nyadera, I. N. (2020). Islam, Politics, and Bangladesh: A Qualitative Content Analysis on the Democratic and Political Culture of Bangladesh Jamaat-e-Islami (BJI). ADAM AKADEMi Sosyal Bilimler Dergisi, 10(2), 291-318. DOI:10.31679/adamakademi.783781

Islam, M. N. (2017). TIKA's Role in Bangladesh Sustainability and Development. Perspective English Magazine, August 2017. Available at: https://perspectivebd.com/archives/1656

Islam, M. N., Bingöl, Y., Nyadera, I. N., \& Dagba, G. (2021). Toward Islam Through Political Parties, Ideology, and Democracy: A Discourse Analysis on Turkey's AK Party, Tunisian Ennahda, and Bangladesh Jamaat-e-Islami. Jadavpur Journal of International Relations, 25(1), 26-51. https://doi.org/10.1177/09735984211019797

Jeferson, R.; Wendt, A. and Katzenstein, P. (1996). 'Norms, Identity, and Culture in National Security', Peter Katzenstein (ed.), The Culture of National Security, (New York: Colombia University Press)

Kalin, I. (2011). Soft Power and Public Diplomacy in Turkey. PERCEPTIONS, Autumn 2011, Volume XVI, Number 3 , pp. 5-23. Center for Strategic Research, Turkey.

Ministry of Foreign Affairs, Turkey. Accessed: 02.01.2018. Retrieved from http://www.mfa.gov.tr/relationsbetween-turkey-egypt.en.mfa

Nyadera, I. N.; \& Islam, M. N. (2020). Transnational Operations, International Reactions, and Legitimacy: The Case of Turkey and Saudi Arabia. Contemporary Review of the Middle East, 7 (3), 1-22. DOI: $10.1177 / 2347798920921965$

Nyadera, I. N.; Islam. M. N. (2020). Link Between Administration, Politics, and Bureaucracy. In: Farazmand A. (eds) Global Encyclopedia of Public Administration, Public Policy, and Governance. Switzerland: Springer, Cham

Nye, J. S. (1990). "Soft Power," Foreign Policy, No. 80, Twentieth Anniversary (Autumn, 1990), pp. 153-171 (19 pages), pp. 154.

Nye, J. S. (2004). Soft Power: The Means to Success in World Politics. New York: PublicAffairs Press; New Ed edition (April 27, 2005) pp. 11.

Nye, J. S. (2006). “Think Again: Soft Power." Foreign Policy (March/April)

OECD Report (2017). Accessed: 02.01.2018Retrieved from http://www.oecd.org/unitedstates/ publicationsdocuments/reports/

Oguzlu, T. (2017). Soft power and US foreign policy. World Analysis News Service, Anadolu Agency (AA). Accessed: 01.01.2018. Retrieved from http://aa.com.tr/en/analysis-news/soft-power-and-us-foreign-policy/908366 
Punch K. F. (1998). Introduction to social research- quantitative and qualitative approaches. Sage Publications, London, pp.-243. ISBN 0761944176

Tan, N. (2010). "Turkish - U.S. Relations in a Changing World" speech at the United States CSIS, July 22, 2010

TIKA Report (2015). Turkish Development Assistance Report. Accessed: 01.01.2018. Retrieved from http://www. tika.gov.tr/upload/2017/YAYINLAR/TKYR\%202015\%20ENG/KALKINMA\%20.pdf

Wendt, A. (1994). 'Collective Identity Formation and the International State', American Political Science Review, $88: 2,384-396$

Wendt, A. (1999). Social Theory of International Politics, (Cambridge: Cambridge University Press)

Yavuz, M. H. (2009)."Turkish Identity and Foreign Policy in Flux: The Rise of Neo-Ottomanism”, Critique 12 (1998), pp. 19-41; also see (Fisher Onar 2009, Taspinar 2008)

Youngs, P. (2001). Districtand State Policy Influences on Professional Development and School Capacity. Educational Policy, 15(2), 278-301. https://doi.org/10.1177/0895904801015002003

Zayed, M. (2013). "Turkish Drama in the Arab World: Social Impacts, Religious Reaction and Dramatic Void in the Arab World". Research in Turkey: Center for Policy and Research in Turkey. Accessed: 08.12.2016. Retrieved from http://researchturkey.org/turkish-drama-in-the-arab-world-social-impacts-religious-reaction-anddramatic-void-in-the-arab-world/

\section{Beyan ve Açılamalar (Disclosure Statements)}

1. Bu çalışmanın yazarları, araştırma ve yayın etiği ilkelerine uyduklarını kabul etmektedirler (The authors of this article confirm that their work complies with the principles of research and publication ethics).

2. Yazarlar tarafından herhangi bir çıkar çatışması beyan edilmemiştir (No potential conflict of interest was reported by the authors).

3. Bu çalışma, intihal tarama programı kullanılarak intihal taramasından geçirilmiştir (This article was screened for potential plagiarism using a plagiarism screening program).

4. Bu makale için etik kurul izni gerekmemektedir (Ethics committee permission is not required for this article). 